\title{
Crystal meth: the forgotten epidemic
}

\section{Opinion}

We first heard about meth in the early 70's, under the slogan "Speed Kills" but it has been around since the 1800's, first synthesized as an asthma medicine, and later as a military crutch under Hitler's regime. He needed a substance that would make his troops lean, mean and fight around the clock with little or no sleep or nourishment. His chemists perfected the concoction, later to be sold as a diet supplement and metabolism enhancer. Once this became evident that there was a demand for it, it went underground to biker gangs starting in Los Angeles with the Hell's Angels and quickly spreading throughout the country as 'crank'. At that time, Vicks Benzedrex inhalers were used to make "bathtub crank", before Desoxyn was eliminated from them in early 90's. In the 80's, P2P was being extracted from Kodak film chemicals for phenethylamine synthesis, as well as red phosphorus, Sudafed, Red Devil lye, kerosene and black iodine, which was bought from horse farmers for use in medicating hooves, especially from the Amish community.

I first experienced it in the late 70's as a teenager, finding it to be exciting and in demand as a definite cash flow enhancer, and I was off to the races. Eventually we had it flown in from California as "LA Glass", as translucent amber chunks of money making enterprise.

This drug has been the bane of many addict's existence, poisoning family values and creating debilitating effects on the family. Legally meth was still somewhat underexposed, as crack cocaine became a huge development in the 80 's throughout the country, shattering all criminal activity records with gang-related deaths and mayhem. But crystal methamphetamine was still very much alive and well in the rural communities. I lived in the Midwest at the time, with Arkansas chicken farms providing some of the precursory elements for the mass production of meth after being extracted from chicken feed. It was well-known at the time how this was happening, and there were recipes going around that created a white 'soapbox' substance that flaked off like bars of soap.

Independence, Missouri became a hotbox of clandestine lab activities in the 90's, and over 600 labs were busted in this small Kansas City bedroom community in one year alone. I happened to live in "Spindependence" at the time, and was well-acquainted with these cooks and lab personnel. Many of them are still in Federal prison or dead; the drug has lasting effects on both the body as well as the legal system. After Sudafed was restricted in 2005 for mass purchase, methamphetamine took an especially ugly turn when the precursors were developed from anhydrous ammonia, creating a run on farmer's Co-ops and tanks left in the fields. There were numerous addicts who attempted to reroute the liquid into their own containers, with horrific results, from debilitating burns to appendages seared off by the extremely volatile chemical. Addicts will find a way to develop what they need to maintain their addiction, at all costs.

Lithium batteries were also used in the cold cook method of creating this vile substance. The neurological as well as physical effects on the body are shocking; we have seen 'tweakers' in constant
Volume 5 Issue 2 - 2018

Terri Schaffner

CEO of Active Recovery, USA

Correspondence: Terri Schaffner, LPC, LAC CCS NCC, LLC 382I Southern Ave Shreveport, LA 7I I06, USA, Tel (318) 9468157, Fax (318) 216-5868, Email terri@activerecoveryla.org

Received: February 20, 2018 | Published: March 05, 2018

agitation weeks after their last hit from prolonged use. The pictures of "Faces of Meth" went viral, and they were a realistic portrayal of how debilitating this drug can be on the body, resulting in cavernous body sores, cracked lips and fingernails and deeply sunken orbs. I was out of the scene at this time, having been incarcerated several times over 23 years and finally in 2001 cleaning up for good. I eventually obtained my Master's degree in Counseling and became a Licensed Addiction Counselor and started Active Recovery, which now boasts three facilities in Northwest Louisiana.

The media presents opioids as the biggest addiction in the nation at this time; yes, it certainly has increased in overdoses and death but crystal meth has made another huge comeback with the increased introduction of extremely high quality meth from the Mexican Cartel at very low prices. San Diego alone had over 20,000 pounds confiscated in 2016. It travels across our superhighways in liquid form or powder in all types of containers and distributed throughout. In Shreveport, Louisiana, we see over 150 meth addicts per month alone. The unintentional victims are children of these meth addicts, the real travesty, as Children and Family Services refer their parents to us for rehabilitation and support. As huge Federal grants are provided for the current opioid epidemic, it should be noted that Crystal Methamphetamine has reared its ugly head as the "Forgotten Epidemic of America".

\section{Acknowledgments}

None.

\section{Conflict of interest}

None. 